Original research article

\title{
Predictors of increased depressive symptoms in the postpartum period
}

\author{
Lubica Banovcinova *, Zuzana Skodova, Kristina Jakubcikova \\ Comenius University, Jessenius Faculty of Medicine, Department of Midwifery, Martin, Slovak Republic
}

\begin{abstract}
Introduction: Pregnancy and the postpartum period are a risk period in a woman's life in terms of manifesting mental disorders, such as postpartum depression. Previous research has identified several risk factors affecting the onset and progression of postpartum depression. Aim: (1) to find the occurrence of depressive symptoms in the postpartum women group; (2) to verify the influence of selected factors on the level of postpartum depression.

Materials and methods: Study sample consisted of 510 mothers in the postpartum period, mean age 30.6 years ( \pm 5.3 ; range 19-45 years). The Edinburgh postnatal depression scale was used to measure symptoms of depression; a questionnaire of our own design was used to assess selected factors potentially influencing level of depressive symptoms.

Results: In the Edinburgh postnatal depression scale, the respondents achieved an average score of $9.3 \pm 5.6$; and the prevalence of severe depressive symptoms was $25.3 \%$. The linear regression model showed that significant predictors of postpartum depression were: lower education; history of depression; dependence on the opinion of others; concerns about future; low satisfaction with motherhood; problems with partner; problems with breast-feeding; tearful child; negative emotions toward the baby; and poor mastering of maternity. Discussion: Significant predictors of postpartum depression identified in this study can be easily detected in clinical practice using the unique long-term contact that a woman has with her prenatal midwife. Evaluation of mothers' emotional health and screening for postpartum depression risk factors can enable midwives to identify those at risk and intervene in a timely manner.
\end{abstract}

Keywords: Depressive symptoms; Edinburgh postnatal depression scale; Postpartum period; Predictors

\section{Introduction}

Pregnancy and the postpartum period are risk periods in the life of a woman in terms of the manifestation of mental disorders. While many women can adapt themselves to developing physiological, psychological, and social changes related to pregnancy and childbirth, some women may develop mental disorders at different levels (Batmaz et al., 2015). The most common disorders include postpartum dejection, postpartum depression, postpartum psychosis, but also post-traumatic stress disorder (Izáková, 2015; Mazúchová et al., 2016a; Söderquist et al., 2009).

Depressive symptoms in the postnatal period are a well-developed topic in the literature, but there is no consensus in its estimated prevalence. In studies dealing with this issue there are large differences due mainly to the fact that the individual measurements are influenced by the methodology, as well as the health, cultural, demographic and socio-economic factors (Halbreich and Karkun, 2006; Tebbe et al., 2013), and the differences in perceptions of mental health and its stigmatization (Halbreich and Karkun, 2006). As a result, the international prevalence of depressive difficulties during pregnancy ranges between 7 and 30 percent (Tebbe et al., 2013). Postpartum depression often remains undiagnosed, because the woman herself considers her condition to be natural (Izáková, 2015; Izáková et al., 2013). Of course, it is not possible for psychiatrists to examine each woman who has just given birth (Izáková, 2015), so midwives should play an important role in identifying women at risk of maternal distress (Seimyr et al., 2013). It seems appropriate to use screening questionnaires such as, for example, the Edinburgh Postnatal Depression Scale (Cox et al., 1987) and the Postpartum Depression Screening Scale (Beck a Gable, 2000), which are not time-consuming and technically easy (Izáková, 2015). They are intended mainly for primary care. It is advisable to repeat the examination after 2 weeks (Bašková, 2015). The use of EPDS during pregnancy can improve the ability of midwives to provide support to women in maternity hospitals (Seimyr et al., 2013) and in the primary care sphere (home care), as non-psychotic depression is manifested later on (Bašková, 2015). Especially for accurate prevention, diagnosis and treatment, further information is needed on the differences between populations with varying degrees of risk in the prevalence and course of postnatal depression (Verkerk et al., 2003).

\footnotetext{
* Author for correspondence: Lubica Banovcinova, Comenius University, Jessenius Faculty of Medicine, Department of Midwifery, Malá Hora 5, Martin 036 01, Slovak Republic; e-mail: banovcinova@jfmed.uniba.sk http://doi.org/10.32725/kont.2018.003

Submitted: 2018-05-18 • Accepted: 2018-10-16 • Prepublished online: 2019-01-11

KONTAKT 21/1: 32-38 • EISSN 1804-7122 • ISSN 1212-4117

(c) 2018 The Authors. Published by University of South Bohemia in České Budějovice, Faculty of Health and Social Sciences.

This is an open access article under the CC BY-NC-ND license.
} 
The previous studies have identified a number of risk (but also protective) factors influencing the onset and progression of postpartum depression. The main risk factors based on which we can predict the onset of postnatal depression include history of a previous depressive episode (Abdollahi et al., 2014; Fiala et al., 2017; Izáková, 2015; Milgrom et al., 2008; Zubaran and Foresti, 2011), prenatal depression (Abdollahi et al., 2014; Rich-Edwards et al., 2006; Zubaran and Foresti, 2011), prenatal anxiety (Austin et al., 2007; Zubaran and Foresti, 2011), postpartum blues (Zubaran and Foresti, 2011), premenstrual syndrome (Lee et al., 2015), lifelong psychiatric disorder (Helle et al., 2015), and family history of depression (Fiala et al., 2017).

The risk of postnatal depression is also higher in mothers with gestational diabetes, recurrent urinary tract infection (Abdollahi et al., 2014), abuse of psychoactive substances, thyroid disorders and other chronic diseases of the mother, for example asthma (Izáková, 2015). Smoking cigarettes at any time during pregnancy and non-use of prenatal vitamins in the first trimester were significantly associated with worse depressive symptoms (Dagher and Shenassa, 2012).

In addition to the mental and physical health problems of mothers, significant predictors of postpartum depression include socio-demographic variables such as younger age (Izáková et al., 2013; Seimyr et al., 2013), lower education (Fiala et al., 2017) and unemployment (Seimyr et al., 2013). An important predictor is also the lack of social support, especially on the part of the partner (Helle et al., 2015; Izáková, 2015; Izáková et al., 2013; Milgrom et al., 2008), a shorter relationship with the partner (Seimyr et al., 2013), or his absence (Fiala et al., 2017; Zubaran and Foresti, 2011). Similarly, socio-economic status (Zubaran and Foresti, 2011), low household income (Abdollahi et al., 2014; Batmaz et al., 2015), or financial difficulties (Rich-Edwards et al., 2006) can contribute to the increased incidence of depressive symptoms during pregnancy and in the postpartum period.

Mother's low self-esteem, the presence of life stressors (Fiala et al., 2017; Zubaran and Foresti, 2011), the stress of parental responsibility, and the difficulty of managing responsibilities are stressors associated with worse depressive symptoms (Dagher and Shenassa, 2012; Zubaran and Foresti, 2011). Women who have given birth due to unplanned and unwanted pregnancies also belong to risk groups (Abdollahi et al., 2014; Faisal-Cury et al., 2017; Fiala et al., 2017; Rich-Edwards et al., 2006; Steinberg and Rubin, 2014; Zubaran and Foresti, 2011). In their study, Fiala et al. (2017) describe, in particular, feelings of unhappiness about unwanted pregnancies that aggravate a woman's psychological well-being and put her at higher risk of postpartum depression.

The known risk factors that coact on postnatal mood disorders can include complicated childbirth, a child requiring increased postnatal care (Izáková et al., 2013), a pathological condition of the newborn (Izáková, 2015; Izáková et al., 2013), child's colic (Dagher and Shenassa, 2012), a newborn with a very low birth weight, the female gender (Helle et al., 2015), the temperament of the child (Izáková, 2015), an adverse start of breastfeeding (Dagher and Shenassa, 2012; Izáková et al., 2013), or the absence of breastfeeding (Fiala et al., 2017).

As reported by Seimyr et al. (2013), limited access to protective factors is associated with a higher degree of maternal distress. Among these the most frequently mentioned are: higher maternal age (Izáková et al., 2013; Seimyr et al., 2013), higher education of mothers (Fiala et al., 2017; Izáková et al., 2013), and existing social base. An uncomplicated birth, good health of the newborn (Izáková et al., 2013), the male gender and family savings also have a positive impact (Fiala et al., 2017).

In their study, Reck et al. (2016) highlight the importance of bonding that can prevent postpartum depression and alleviate stress from parenthood. The results of research in this area highlight the need to promote bonding and mother-child interaction to avoid disrupting the relationship between mother and child (Mazúchová et al., 2016b; Reck et al., 2016). The beneficial effect of early skin-to-skin contact on breastfeeding is also described (Mazúchová et al., 2016a).

Higher self-efficacy of women for maternity and self-esteem also has a potentially protective effect on the development of psychiatric disorders during both the pregnancy and postpartum period (Abdollahi et al., 2014).

Similarly, the results of the study by Ding et al. (2014), dealing with the correlation of epidural analgesia and the risk of developing PPD, indicate that epidural analgesia is associated with a lower risk of postpartum depression.

Postpartum depression affects all aspects of a woman's life, including her relationship with her partner and her child's development (Abdollahi et al., 2014). Examining potential risk factors for depressive disorders can help to better target preventive interventions for threatened mothers and children (Martini et al., 2015).

The aim of our study was (1) to detect the occurrence of depressive symptoms in a postpartum women group; (2) to verify the influence of selected factors on the degree of postpartum depression.

\section{Materials and methods}

\section{Study design}

The study used a cross-sectional design to elicit information about risk factors of maternal distress and risk for postpartum depression.

\section{Participants}

We used the convenience sampling method to recruit participants to our study. The research sample consisted of 510 women in the postpartum period. The average age of respondents was 30.6 years $( \pm 5.3)$. The minimum age was 19 years and the maximum age 45 years. Most women who participated in the survey were in the $30-39$ age group (52.7\%). Women of 29 years and under were $41.5 \%$ and the smallest group (5.8\%) were women aged 40 and over. Respondents who achieved higher education were $56.2 \%$, and $39.8 \%$ of women achieved secondary education. A lower level of education was reported by $4.1 \%$ of respondents. Most women who participated in the survey gave birth once (60.8\%). Women who gave birth two or more were $39.2 \%$. The largest percentages were married women $(71.5 \%)$, and then single (9.0\%), in a relationship (17.1\%) and divorced (2.3\%).

\section{Measures}

The quantitative data were collected using two questionnaires The Edinburgh Postnatal Depression Scale (EPDS) (Cox et al., 1987) was used to measure symptoms of maternal distress and depression after childbirth. This self-report scale includes ten items, all items are scored on a four-point response from 0 to 3. The scale indicates how the mother has felt during the previous week. Mothers who score above 13 are likely to be suffering from a depressive illness of varying severity. The EPDS score should not override clinical judgment. A careful clinical assessment should be carried out to confirm the diagnosis. 
However, the EPDS is easy to administer and has proven to be an effective screening tool. The Edinburgh Postnatal Depression Scale was translated into Slovak and then back-translated in order to check that the questions elicited the intended information. The internal consistency measured by Cronbach's alpha was 0.985 .

The second questionnaire of our own design was used to assess selected factors potentially influencing level of depressive symptoms (EPDS): socio-demographic characteristics (i.e. age, marital status, level of marital satisfaction, education, socioeconomic status), risk factors for mental disorders (i.e. family history and past history of psychological problems), obstetric characteristics (i.e. parity, breast feeding, pregnancy intention, mode of delivery, epidural analgesia) and psychological characteristics (i.e. self-esteem, ability to express emotions, satisfaction with motherhood).

\section{Data collection}

The survey was conducted in February-March 2016. The questionnaire was distributed in a local gynaecological outpatient clinic based on the doctor's oral approval and via the Internet. The total number of questionnaires was 510, of which 60 questionnaires were from the gynaecological clinic and 450 questionnaires were collected via the Internet. The questionnaire response rate of the gynaecological clinic was $75 \%$.

\section{Ethical consideration}

The research ethics committee of the University Hospital in Martin, Slovakia, reviewed and approved the research protocol.

\section{Statistical analysis}

Answers from the questionnaire of our own design were converted into dichotomous (yes/no) variables to enter into the regression model. Logistic regression was used when multiple variables were considered simultaneously. Odds ratios (OR) were presented with $95 \%$ confidence intervals (CI). Statistical significance was defined as two-sided $\mathrm{p}$ values using a significance level of $5 \%$.

\section{Results}

Mother's mean age was $30.6 \pm 5.3$ years. The majority $(63.3 \%)$ were primiparous, married or living in long-term relationship (88\%), had university education level (56.3\%), and had undergone vaginal delivery (65.9\%) (Table 1 ).

In the EPDS scale, the respondents achieved an average score of 9.3 . When applying a cut-off score of 13 points, scores of 129 (25.3\%) respondents indicated severe levels of depressive symptoms.

The linear regression model showed that significant predictors of postpartum depression were (Table 2): lower education $[\beta=-0.079 ; 95 \% C I=(-1.477 ;-0.007)]$; history of depression $[\beta=0.287 ; 95 \% C I=(0.680 ; 3.005)]$; dependence on the opinion of others $[\beta=-0.097 ; 95 \% \mathrm{CI}=(0.252 ; 2.010)]$; concerns about future $[\beta=0.097 ; 95 \% C I=(0.617 ; 1.576)]$; low satisfaction with motherhood $[\beta=-0.132 ; 95 \% C I=(-2.847 ;-0.680)]$; problems with partner $[\beta=-0.090 ; 95 \% C I=(-1.239 ;-0.042)]$; problems with breast-feeding $[\beta=0.82 ; 95 \% C I=(0.062$; $1.124)]$; tearful child $[\beta=0.089 ; 95 \% C I=(0.068 ; 1.040)]$; negative emotions toward the baby $[\beta=-0.170 ; 95 \% C I=(-2.806$; $-1.029)]$; and poor mastering of maternity $[\beta=-0.167 ; 95 \%$ $C I=(-2.303 ;-0.718)]$.

\begin{tabular}{|c|c|c|}
\hline Characteristics & mean $( \pm S D$, range $)$ & $n(\%)$ \\
\hline Maternal age & $30.60( \pm 5.3 ; 19-45)$ & \\
\hline \multicolumn{3}{|l|}{ Parity } \\
\hline Primiparous & & $323(63.3)$ \\
\hline Multiparous & & $187(36.7)$ \\
\hline History of miscarriage(s) & & $96(18.8)$ \\
\hline \multicolumn{3}{|l|}{ Marital status } \\
\hline Married/with partner & & $449(88.0)$ \\
\hline Single/without partner & & $56(11.0)$ \\
\hline \multicolumn{3}{|l|}{ Education status } \\
\hline Primary education & & $4(0.8)$ \\
\hline Secondary school education & & $218(42.7)$ \\
\hline University education & & $287(56.3)$ \\
\hline History of psychological problems & & $72(14.1)$ \\
\hline Family history of depression & & $92(18.0)$ \\
\hline \multicolumn{3}{|l|}{ Delivery method } \\
\hline Vaginal delivery & & $336(65.9)$ \\
\hline Planned caesarean section & & $74(14.5)$ \\
\hline Urgent caesarean section & & $100(19.6)$ \\
\hline
\end{tabular}

The other factors did not predict high levels of postpartum depression. The total explained variance in the linear regression model was $55.1 \%$.

\section{Discussion}

The aim of our study was to determine the influence of risk factors on the onset of postnatal depression in postpartum women. The basis of our research was the Edinburgh Postnatal Depression Scale questionnaire, and a questionnaire that we designed, focusing on each risk factor.

In our study, the prevalence of depressive symptoms (EPDS $\geq 13$ points) was $25.3 \%$. The most commonly reported mean incidence of postnatal depression is $10-15 \%$ (Fiala et al., 2017; Izáková, 2015), but there are large differences in the prevalence among studies (Batmaz et al., 2015; Halbreich and Karkun, 2006; Tebbe et al., 2013). In their longitudinal study, Fiala et al. (2017) monitored a group of 3.2 Czech women for the occurrence of depressive symptoms using EPDS, finding the prevalence of depression 6 weeks after birth (11.8\%) and 6 months after birth (10.1\%). On the other hand, Batmaz et al. (2015) based on the results of their study, reported $18.3 \%$ of postnatal depression in a group of 170 Turkish mothers. Kumwar et al. (2015), who examined depression in a sample of 100 Nepalese women, found it in $29 \%$ of cases (mean EPDS score was $10.3 ; S D= \pm 4.0$ ).

The linear regression model showed that the education status was a significant socio-demographic predictor for postpartum depression among women in the postpartum period. Respondents with lower education achieved higher scores in postnatal depression compared to mothers with higher education. In a Turkish study led by Inandi et al. (2002), a statistically significant association between low education and postpartum depression was found, whereas Batmaz et al. (2015) did not find such a correlation.

Other risk factors we examined were the economic and social situation of mothers. As a significant predictor of postnatal depressive symptoms, a conflicting partnership relationship was confirmed in our sample, whereas the family's financial 
Table 2. Linear regression model with the effect of selected variables (socio-demographic, psycho-social and obstetric characteristics) on postpartum depression

\begin{tabular}{|c|c|c|c|c|}
\hline & $\beta$ & $p$ & $95^{\circ}$ & or B \\
\hline & & & Lower bound & Upper bound \\
\hline Age & 0.56 & 0.190 & -0.030 & 0.150 \\
\hline Marital status & -0.014 & 0.710 & -1.656 & 1.128 \\
\hline Education & -0.078 & 0.048 & -1.477 & -0.007 \\
\hline Epidural analgesia & -0.030 & 0.425 & -1.356 & 0.573 \\
\hline Mode of delivery & 0.014 & 0.748 & -0.540 & 0.751 \\
\hline Satisfaction with labour & 0.042 & 0.307 & -0.306 & 0.970 \\
\hline Course of labour & 0.018 & 0.650 & -0.743 & 1.188 \\
\hline Parity & 0.038 & 0.416 & -0.638 & 1.541 \\
\hline History of miscarriage(s) & -0.034 & 0.363 & -1.584 & 0.582 \\
\hline PMS & 0.039 & 0.294 & -0.397 & 1.309 \\
\hline Depression in family & -0.040 & 0.274 & -0.878 & 0.249 \\
\hline History of depression & 0.287 & 0.002 & 0.680 & 3.005 \\
\hline Antenatal education & 0.004 & 0.921 & -0.903 & 0.999 \\
\hline Emotions after labour & -0.065 & 0.084 & -1.320 & 0.084 \\
\hline Dependence on the opinion of others & 0.097 & 0.012 & 0.252 & 2.010 \\
\hline Concerns about future & 0.186 & 0.000 & 0.617 & 1.576 \\
\hline Satisfaction with motherhood & -0.132 & 0.001 & -2.847 & -0.680 \\
\hline Pessimism & 0.059 & 0.157 & -0.303 & 1.874 \\
\hline Expression of emotions & -0.028 & 0.503 & -0.813 & 0.400 \\
\hline Self-esteem & -0.066 & 0.119 & -1.864 & 0.214 \\
\hline Satisfaction with finances & 0.029 & 0.460 & -0.346 & 0.762 \\
\hline Pregnancy intent & 0.012 & 0.768 & -0.783 & 1.061 \\
\hline Readiness for motherhood & -0.051 & 0.247 & -1.271 & 0.328 \\
\hline Problems with partner & -0.090 & 0.036 & -1.239 & -0.042 \\
\hline Disabled child & -0.019 & 0.612 & -4.081 & 2.407 \\
\hline Preterm delivery & 0.005 & 0.899 & -0.627 & 0.714 \\
\hline Problems with breast-feeding & 0.082 & 0.029 & 0.061 & 1.124 \\
\hline Worries about the child & 0.73 & 0.055 & -0.017 & 1.697 \\
\hline Tearful child & 0.089 & 0.026 & 0.068 & 1.040 \\
\hline Emotions toward the baby & -0.170 & 0.000 & -2.806 & -1.029 \\
\hline Synchronisation of needs & -0.056 & 0.191 & -2.217 & 0.443 \\
\hline Mastering maternity & -0.167 & 0.000 & -2.303 & -0.718 \\
\hline Bonding & -0.051 & 0.273 & -0.998 & 0.283 \\
\hline
\end{tabular}

situation was not ascertained. In their studies, Asselmann et al. (2016) and Martini et al. (2015) found a strong relationship between a lack of social support and the emergence of postpartum depression and anxiety disorders. The mother's good social background and, in particular, a long-term, non-conflictual relationship with a partner/spouse is a significant protective factor (Izáková et al., 2013; Seimyr et al., 2013).

A statistically significant association was observed between the presence of a depressive episode after previous birth and the current depressive symptoms. Similar results were also reported in a Batmaz et al. (2015) study where they found a significantly higher risk of postpartum depression in wom- en who had previously had depression, and reported depression history as the most significant risk factor for postpartum depression. Similarly, Seimyr et al. (2013) report that mental health problems, especially depression, are a strong risk factor for postpartum depression, while the incidence of mental disorders in the family did not affect the stress and depression of the respondents $(N=283)$ during the pregnancy and postpartum period. As Pidermann (2006) states, the overall psychological faculties of a woman, psychological problems in the past, or disease or heritability, can play their part in the onset and course of postpartum depression. 
The respondents in our study who reported dependence on the judgement of their surroundings and who experience increased fears about the future were more susceptible to the development of postnatal depression. However, according to Seimyr et al. (2013), worries and fears are associated with maternal responsibility rather than postpartum depression. Dependence on the views of others may be associated with low self-esteem and uncertainty in a new unusual situation.

On the other hand, subjective satisfaction with motherhood and management of the duties associated with it can be considered, on the basis of our results, as protective factors that reduce the occurrence of depressive symptoms in the postpartum period. The study of Abdollahi et al. (2014) found that a lack of postnatal parental competence and low parenting self-efficacy were significant risk factors for postpartum depression. On the other hand, women who have a positive view of their maternal capabilities were found to be more able to care for the infant with confidence immediately after birth.

An increased risk of postpartum depression was also closely related to reports by the respondents of an indifferent relationship to the baby shortly after birth and problems with breasts and breastfeeding. The negative impact of persistent problems with breastfeeding, or completely impossible breastfeeding, on the psychological wellbeing of mothers was proven also by Izáková et al. (2013) According to these authors, the mother's best efforts to cope with lactation can be supported by the fact that breastfeeding is currently much appreciated and highlighted by both experts and society. Maternal insufficiency in breastfeeding in the first days after birth, often biologically conditioned by a later onset of lactation, e.g. due to operative delivery, may contribute to the manifestation of depressive symptoms (Izáková, 2015; Izáková et al., 2013).

One of the factors associated with the occurrence of depressive symptoms is also the temperament of the child (Izáková, 2015). A crying baby requiring increased attention of the mother contributed to the development of psychological problems in the women in our study. Similarly, Petzoldt et al. (2016) found a correlation between anxiety and depressive disorders of mothers and breastfeeding problems, crying babies and babies with sleep disorders. The research led by Kumwar et al. (2015) proved an association between the child's health problem and postnatal depression, but this was not confirmed in our study.

Although several studies have proved the relationship between birth characteristics such as birth complications (Izáková et al., 2013), type of delivery (Patel et al., 2005), epidural analgesia (Ding et al., 2014), bonding (Reck et al., 2016), etc., and postpartum depression, our study did not confirm this relationship. Similarly, the study by Bell et al. (2016), which examined the relation of the course of childbirth and symptoms of postpartum depression, did not confirm the relationship between the type of childbirth and complications during and after birth and postpartum depression. However, regardless of the clinical postnatal birth assessment, women may experience childbirth as a traumatism, which has a negative impact on their wellbeing and mental processing of the event (Seimyr et al., 2013).

\section{Limitations of the study}

We have seen several limitations in the study that negatively affect the validity of the presented results. The focal group was a random sample of midwifery clients who completed the online questionnaire. The response rate was relatively high, which is common with the use of electronic media. However, the disadvantage of electronic media may be the selection of a relatively privileged group that does not represent the entire target population. The research sample was characterized by a relatively high educational level and a high proportion of primiparas. Participation in the study was voluntary, which may have influenced the prevalence of reported psychological difficulties (Tebbe et al., 2013).

The use of the self-assessment scale and the questionnaire, which reflect the subjective perception of respondents, can be also considered a limitation and thus the data obtained may be subject to considerable distortion. The use of a non-standardized questionnaire could have resulted in misclassification of information and lack of comparability of results to those of prior studies that have used standard instruments.

\section{Conclusions}

Risk factors of postpartum depression include lower education of the mother, psychological problems after previous birth and in puerperium, women's dependence on their social background's judgement, tendency to experience fear of the future, low satisfaction with maternity and a negative judgement on coping with maternity, partnership/marriage problems, problems with breastfeeding, crying baby and an indifferent to negative relationship to the baby after birth. These risk factors can significantly affect the psyche of a woman in the postpartum period, thereby contributing to the emergence of postpartum depression. Therefore, it is necessary to focus on the implementation of the acquired knowledge and finding effective ways of early intervention to prevent and mitigate depressed mood. These interventions should take advantage of the unique long-term contact that a woman has with her midwife. Staying in touch with mothers frequently during pregnancy and the postpartum period provides an opportunity for health service professionals to evaluate the mother's emotional health and to screen for postpartum depression risk factors to identify those at risk and intervene in a timely manner.

\section{Conflict of interests}

The authors declare that they have no conflict of interests. 


\section{Prediktory zvýšených depresivních přiznaků v poporodním období}

\section{Souhrn}

Úvod: Těhotenství a poporodní období jsou rizikovým obdobím v životě ženy, pokud jde o projev duševních poruch, jako je poporodní deprese. Předchozí výzkum identifikoval několik rizikových faktorů ovlivňujících nástup a průběh poporodní deprese. Cíl: (1) zjištění výskytu depresivních příznaků u skupiny žen po porodu; (2) ověření vlivu vybraných faktorů na úrovni poporodní deprese.

Metodika: Vzorek byl sestaven z 510 matek v poporodním období v průměrném věku 30,6 let ( \pm 5,3, v rozmezí 19-45 let). Na měření postnatální deprese byla použita Edinburská škála k měření symptomů deprese a vlastní dotazník byl použit k posouzení vybraných faktorů, které by mohly ovlivnit úroveň symptomů deprese.

Výsledky: Na Edinburské škále respondenti dosáhli průměrného skóre 9,3 $\pm 5,6$; prevalence závažných depresivních symptomů byla 25,3 \%. Lineární regresní model ukázal, že významnými prediktory deprese po porodu byly: nižší vzdělání; historie deprese; závislost na názorech druhých; obavy ohledně budoucnosti; nízká úroveň spokojenosti s mateřstvím; problémy s partnerem; problémy s kojením; plačtivé dítě; negativní emoce vůči dítěti; špatné zvládnutí mateřství.

Diskuse: Významné prediktory poporodní deprese identifikované $\mathrm{v}$ této studii lze snadno zjistit v klinické praxi pomocí jedinečného dlouhodobého kontaktu, který má žena s její prenatální porodní asistentkou. Vyhodnocení emočního zdraví matek a screening rizikových faktorů poporodní deprese mohou umožnit porodním asistentkám identifikovat ty rizikové a zasáhnout včas.

Klíčová slova: Edinburská škála poporodní deprese; poporodní období; prediktory; příznaky deprese

\section{References}

1. Abdollahi F, Zarghami M, Azhar MZ, Sazlina SG, Lye MS (2014). Predictors and incidence of post-partum depression: a longitudinal cohort study. J Obstet Gynaecol Res 40(12): 2191-2200. DOI: 10.1111/jog.12471.

2. Asselmann E, Wittchen HU, Erler L, Martini J (2016). Peripartum changes in social support among women with and without anxiety and depressive disorders prior to pregnancy: a prospective-longitudinal study. Arch Womens Ment Health 19(6): 943-952. DOI: 10.1007/s00737-016-0608-6.

3. Austin MP, Tully L, Parker G (2007). Examining the relationship between antenatal anxiety and postnatal depression. J Affect Disord 101(1-3): 169-174. DOI: 10.1016/j.jad.2006.11.015.

4. Bašková M (2015). Metodika psychofyzické přípravy na porod. Praha: Grada.

5. Batmaz G, Dane B, Sarioglu A, Kayaoglu Z, Dane C (2015). Can we predict postpartum depression in pregnant women? Clin Exp Obstet Gynecol 42(5): 605-609. DOI: 10.12891/ ceog1910.2015.

6. Beck CT, Gable RK (2000). Postpartum Depression Screening Scale: development and psychometric testing. Nurs Res 49(5): 272-282. DOI: 10.1097/00006199-200009000-00006.

7. Bell AF, Carter CS, Davis JM, Golding J, Adejumo O, Pyra M, et al. (2016). Childbirth and symptoms of postpartum depression and anxiety: a prospective birth cohort study. Archives of Women's Mental Health 19(2): 219-227. DOI: 10.1007/s00737015-0555-7.

8. Cox JL, Holden JM, Sagovsky R (1987). Detection of postnatal depression: Development of the 10-item Edinburgh Postnatal Depression Scale. Br J Psychiatry 150: 782-786. DOI: 10.1192/ bjp.150.6.782.

9. Dagher RK, Shenassa ED (2012). Prenatal health behaviors and postpartum depression: is there an association? Arch Womens Ment Health 15(1): 31-37. DOI: 10.1007/s00737-011-0252-0.

10. Ding T, Wang DX, Qu Y, Chen Q, Zhu SN (2014). Epidural labor analgesia is associated with a decreased risk of postpartum depression: a prospective cohort study. Anesth Analg 119(2): 383-392. DOI: 10.1213/ANE.0000000000000107.

11. Faisal-Cury A, Menezes PR, Quayle J, Matijasevich A (2017). Unplanned pregnancy and risk of maternal depression: secondary data analysis from a prospective pregnancy cohort. Psychol Health Med 22(1): 65-74. DOI: 10.1080/13548506.2016.1153678.

12. Fiala A, Švancara J, Klánová J, Kašpárek T (2017). Sociodemographic and delivery risk factors for developing postpartum depression in a sample of 3233 mothers from the Czech ELSPAC study. BMC Psychiatry 17(1): 104. DOI: 10.1186/ s12888-017-1261-y.

13. Halbreich U, Karkun S (2006). Cross-cultural and social diversity of prevalence of postpartum depression and depressive symptoms. J Affect Disord 91(2-3): 97-111. DOI: 10.1016/j. jad.2005.12.051.

14. Helle N, Barkmann C, Bartz-Seel J, Diehl T, Ehrhardt S, Hendel A, et al. (2015). Very low birth-weight as a risk factor for postpartum depression four to six weeks postbirth in mothers and fathers: Cross-sectional results from a controlled multicentre cohort study. J Affect Disord 180:154-161. DOI: 10.1016/j.jad.2015.04.001.

15. Inandi T, Elci OC, Ozturk A, Egri M, Polat A, Sahin TK (2002). Risk factors for depression in postnatal first year, in eastern Turkey. Int J Epidemiol 31(6): 1201-1207. DOI: 10.1007/ s00127-005-0949-3.

16. Izáková L' (2015). Duševné zdravie počas tehotenstva a po pôrode. Psychiatria pre prax 16(3): 18-20.

17. Izáková L', Borovská M, Baloghová B, Krištúfková A (2013). Výskyt depresívnych príznakov $\mathrm{v}$ popôrodnom období. Psychiatria pre prax 14(2):75-78.

18. Kumwar D, Corey EK, Sharma P, Risal A (2015). Screening for Postpartum Depression and Associated Factors among Women who Deliver at a University Hospital, Nepal. Kathmandu Univ Med J (KUMJ) 13(1): 44-48. DOI: 10.3126/kumj.v13i1.13752.

19. Lee YJ, Yi SW, Ju DH, Lee SS, Sohn WS, Kim IJ (2015). Correlation between postpartum depression and premenstrual dysphoric disorder: Single center study. Obstet Gynecol Sci 58(5): 353-358. DOI: 10.5468/ogs.2015.58.5.353.

20. Martini J, Petzoldt J, Einsle F, Beesdo-Baum K, Höfler M, Wittchen HU (2015). Risk factors and course patterns of anxiety and depressive disorders during pregnancy and after delivery: a prospective-longitudinal study. J Affect Disord 175: 385-395. DOI: 10.1016/j.jad.2015.01.012.

21. Mazúchová L, Kelčíková S, Vasil'ková P (2016b). Informovanost' žien o bondingu. Pediatr praxi 17(2): 122-125.

22. Mazúchová L, Kelčíková S, Vasil'ková P, Buchanec J (2016a). Podpora bondingu po pôrode. Česko-Slovenská Pediatrie 71(4): 196-201.

23. Milgrom J, Gemmill AW, Bilszta JL, Hayes B, Barnett B, Brooks J, et al. (2008). Antenatal risk factors for postnatal depression: A large prospective study. J Affect Disord 108(1-2): 147-157. DOI: 10.1016/j.jad.2007.10.014.

24. Patel RR, Murphy DJ, Peters TJ (2005). Operative delivery and postnatal depression: a cohort study. BMJ 330(7496): 879 DOI: 10.1136/bmj.38376.603426.D3. 
25. Petzoldt J, Wittchen HU, Einsle F, Martini J (2016). Maternal anxiety versus depressive disorders: specific relations to infants' crying, feeding and sleeping problems. Child Care, Health Dev 42(2): 231-245. DOI: $10.1111 /$ cch.12292.

26. Pidermann V (2006). Žena a poruchy nálady. Praha: Galén.

27. Reck C, Zietlow AL, Müller M, Dubber S (2016). Perceived parenting stress in the course of postpartum depression: the buffering effect of maternal bonding. Arch of Womens Ment Health 19(3): 473-482. DOI: 10.1007/s00737-015-0590-4.

28. Rich-Edwards JW, Kleinman K, Abrams A, Harlow BL, McLaughlin TJ, Joffe, H., et al. (2006). Sociodemographic predictors of antenatal and postpartum depressive symptoms among women in a medical group practice. J Epidemiol Community Health 60(3): 221-227. DOI: 10.1136/ jech.2005.039370.

29. Seimyr L, Welles-Nyström B, Nissen E (2013). A history of mental health problems may predict maternal distress in women postpartum. Midwifery 29(2): 122-131. DOI: 10.1016/j. midw.2011.11.013.

30. Söderquist J, Wijma B, Thorbert G, Wijma K (2009). Risk factors in pregnancy for post-traumatic stress and depression after childbirth. BJOG 116(5): 672-680. DOI: 10.1111/j.14710528.2008.02083.x.
31. Steinberg JR, Rubin LR (2014). Psychological Aspects of Contraception, Unintended Pregnancy, and Abortion. Policy Insights Behav Brain Sci 1(1): 239-247. DOI: $10.1177 / 2372732214549328$

32. Tebbe BBM, Terluin B, Koelewijn JM (2013). Assessing psychological health in midwifery practice: A validation study of the Four-Dimensional Symptom Questionnaire (4DSQ), a Dutch primary care instrument. Midwifery 29(6): 608-615. DOI: 10.1016/j.midw.2012.05.004.

33. Verkerk GJM, Pop VJM, Van Son MJM, Van Heck GL (2003). Prediction of depression in the postpartum period: a longitudinal follow-up study in high-risk and low-risk women. J Affect Disord 77(2): 159-166. DOI: 10.1016/S01650327(02)00146-5.

34. Zubaran C, Foresti K (2011). Investigating quality of life and depressive symptoms in the postpartum period. Women Birth 24(1): 10-16. DOI: 10.1016/j.wombi.2010.05.002 